\title{
Complex mediation of uterine endometrial epithelial cell growth by insulin-like growth factor-II (IGF-II) and IGF-binding protein-2
}

\author{
L Badinga ${ }^{1}$, S Song ${ }^{2}$, R C M Simmen ${ }^{1}$, J B Clarke ${ }^{3}$, D R Clemmons ${ }^{3}$ \\ and F A Simmen ${ }^{2}$ \\ ${ }^{1}$ Interdisciplinary Concentration in Animal Molecular and Cell Biology, Department of Animal Science, \\ University of Florida, Gainesville, Florida 32611, USA \\ ${ }^{2}$ Dairy and Poultry Sciences, University of Florida, Gainesville, Florida 32611, USA \\ ${ }^{3}$ Department of Medicine, University of North Carolina, Chapel Hill, North Carolina 27599, USA
}

(Requests for offprints should be addressed to F A Simmen, Department of Dairy and Poultry Sciences, PO Box 110920, University of Florida, Gainesville, Florida 32611-0920, USA; Email: simmen@dps.ufl.edu.)

(S Song is now at Department of Molecular Genetics and Microbiology, University of Florida, Gainesville, Florida 32610, USA)

\begin{abstract}
The coexpression of IGF (-I and -II) peptides, corresponding receptors, and IGF binding proteins (IGFBPs) in uterine endometrium suggests that a significant component of IGF action in this tissue is via autocrine or paracrine pathways, or both. The present study examined whether IGF-II and a major uterine-expressed IGF-II binding protein, IGFBP-2, modulate endometrial epithelial cell mitogenesis. Serum-deprived porcine endometrial glandular epithelial (GE) cells of early pregnancy were treated with various concentrations of IGFs, recombinant porcine (rp) IGFBP-2, or both, and examined for changes in cellular mitogenesis by incorporation of $\left[{ }^{3} \mathrm{H}\right]$ thymidine into DNA. Recombinant human (rh) IGF-II stimulated DNA synthesis in a dose-dependent manner. Human $\left[\mathrm{Leu}^{27}\right]-\mathrm{IGF}-\mathrm{II}$, an analog with selective affinity for the IGF-II (type II) receptor, increased thymidine uptake by twofold compared with untreated GE cells. When added in combination with an equimolar concentration of rhIGF-I, $\left[\mathrm{Leu}^{27}\right]$-IGF-II or rhIGF-II stimulated thymidine incorporation to a
\end{abstract}

greater extent than did rhIGF-I alone. Ligand blot analysis of GE cell conditioned medium revealed the presence of four IGFBPs with molecular masses of 48, 31, 23, and $15 \mathrm{kDa}$. Physiological concentrations of rpIGFBP-2 (nM range) increased both basal and IGF-induced DNA synthesis in GE cells. At equimolar concentrations, Des(1-6)IGF-II (an IGF-II analog with much reduced affinity for IGFBPs) and rpIGFBP-2 had additive effects on GE cell mitogenesis, suggesting that the IGFBP-2 modulation of uterine cell growth may involve both IGF-dependent and IGF-independent pathways. Our results demonstrate the complex interplay of IGF system components in uterine endometrial epithelial growth regulation in vitro, identify IGF-II and IGFBP-2 as locally coexpressed uterine epithelial cell mitogens, and suggest the presence of a functional signaling pathway by which IGF-II stimulates epithelial cell proliferation via the type II receptor.

Fournal of Molecular Endocrinology (1999) 23, 277-285

\section{INTRODUCTION}

The uterus undergoes hyperplasia in addition to morphological and functional differentiation during estrous cycles and pregnancy. These physiological states are characterized by highly coordinated changes in endometrial and myometrial mRNA expression of insulin-like growth factors (IGFs), IGF receptors and IGF binding proteins (IGFBPs) - the IGF system. In the uterus of several species, including the pig and rat, IGF-I mRNAs predominate in early pregnancy, whereas IGF-II mRNA accumulation occurs primarily after implantation (Letcher et al. 1989, Pescovitz et al. 1991, Simmen 
et al. 1992), suggesting that these mitogens have either distinct or overlapping actions at the embryo-maternal and feto-maternal interfaces, respectively. The high peri-implantation expression of the $I G F-I$ gene in porcine uterus coincides temporally with increased uterine luminal fluid IGF-I content (Simmen et al. 1989), elongation of spherical blastocysts to the filamentous morphology (Geisert et al. 1982), and transient conceptus secretion of estrogens (Gadsby et al. 1980, Pusateri et al. 1990, Green et al. 1995), which are paracrine regulators of endometrial function, possibly in concert with endometrial-synthesized IGF-I. Because uterine endometrium and myometrium manifest relatively high levels of IGF receptors (Ghahary \& Murphy 1989, Talavera et al. 1990, Hofig et al. 1991), it is speculated that these peptide ligands constitute important autocrine/paracrine effectors of coordinate uterine and embryonic development.

In most of the tissue and cell systems examined to date, the mitogenic actions of IGF-I and IGF-II are considered to be mediated by the IGF-I (type I) receptor (reviewed in Jones \& Clemmons 1995). The role of the IGF-II/cation-independent mannose-6-phosphate (type II) receptor in IGF-II signaling is less clear, and somewhat controversial. Previous attempts to examine which IGF receptor subtype mediates a specific effect(s) of IGF have used anti-receptor antibodies (Jones \& Clemmons 1995). However, under certain experimental conditions, these antibodies do not result in either complete or partial inhibition of binding (Casella et al. 1986, Misra et al. 1986, Kojima et al. 1988, Steele-Perkins \& Roth 1990) and, instead, appear to function as IGF receptor agonists (Kojima et al. 1988, Steele-Perkins et al. 1988). The recent availability of human $\left[\mathrm{Leu}^{27}\right]-\mathrm{IGF}-\mathrm{II}$, an analog with highly selective affinity for the IGF-II receptor (Beukers et al. 1991, Bürgisser et al. 1991, Sakano et al. 1991), has allowed re-examination of the IGF receptor subtype that mediates IGF-II-induced cell mitogenesis.

In addition to their receptors, the biological actions of IGFs also are modulated by a family of structurally related IGFBPs, present in many biological fluids, cell cultures and tissues (Rechler 1993, Jones \& Clemmons 1995). These proteins share the ability to bind IGF-I and IGF-II with high affinity, and often are associated with cell membranes, extracellular matrix, or both, where they may influence IGF-IGF receptor interactions and possibly exert IGF-independent functions (Rechler 1993, Jones \& Clemmons 1995). Although the complete mechanism(s) of action has not been fully defined for any of the IGFBPs, these proteins can augment or inhibit IGF action, depending upon the nature of the IGFBP, the cell context and the experimental conditions. Uterine endometrial expression of IGFBP-2 has been demonstrated in the human (Giudice et al. 1991), pig (Simmen et al. 1992, Song et al. 1996), and rat (Cerro \& Pintar 1997), in addition to other species. In pregnant pig uterus, the abundance of IGFBP-2 mRNA and protein is induced during late pre-implantation (around day 15, postestrus) and reaches maximal levels by mid-pregnancy (day 60) (Simmen et al. 1992, Song et al. 1996). This temporal expression pattern mimics that for endometrial epithelial IGF-II (Simmen et al. 1992), and implicates a physiological role(s) for IGFBP-2 and IGF-II in implantation events and subsequent feto-maternal interactions. However, the biological nature of these presumed roles and the functional interdependency of the two proteins remain unknown for any species.

In the present study, we have examined the individual effects and potential functional interactions of IGF-II and IGFBP-2 on uterine epithelial cellular mitogenesis, using primary cultures of porcine uterine endometrial glandular epithelial (GE) cells of early pregnancy (day 12, postestrus), which express low amounts of endogenous IGFBP-2 relative to later pregnancy stages. Here, we demonstrate the stimulatory effects of IGFBP-2 on basal and exogenous IGF-II-induced DNA synthesis in normal endometrial epithelial cells and begin to clarify the pathway(s) through which IGF-II and IGFBP-2 modulate endometrial epithelial cell proliferation.

\section{MATERIALS AND METHODS}

\section{Materials}

Recombinant human (rh) IGF-I and rhIGF-II peptides were purchased from Upstate Biotechnology (UBI, Lake Placid, NY, USA). [ $\left.\mathrm{Leu}^{27}\right]$ IGF-II and Des(1-6)IGF-II were obtained from GroPep Pty, Ltd (North Adelaide, Australia). Cell culture media and TRIzol were from Gibco-Brl (Gaithersburg, MD, USA). Antibiotic-antimycotic solution (ABAM) and fetal bovine serum (FBS) were from Sigma Chemical Co. (St Louis, MO, USA). $\left[{ }^{3} \mathrm{H}\right]$ Thymidine (specific activity $6.7 \mathrm{Ci}$ / $\mathrm{mmol}$ ), $\left[\alpha_{-}{ }^{32} \mathrm{P}\right]$ deoxycytidine triphosphate (specific activity $3000 \mathrm{Ci} / \mathrm{mmol}$ ) and BioTrans nylon membranes $(0.2 \mu \mathrm{m})$ were purchased from ICN Pharmaceuticals (Irvine, CA, USA). Nitrocellulose membranes $(0 \cdot 2 \mu \mathrm{m})$ were obtained from Schleicher and Schuell (Keene, NH, USA). 


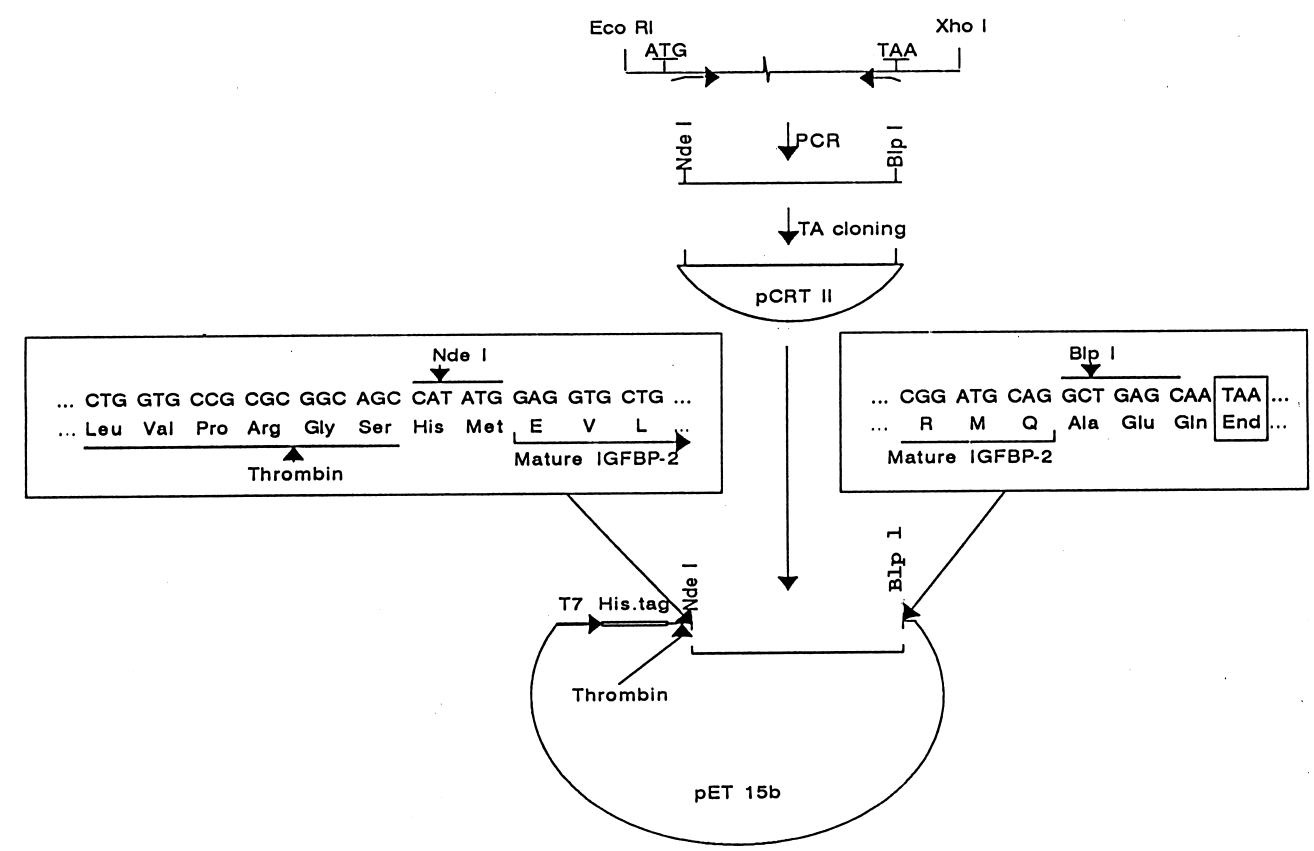

FIGURE 1. Bacterial expression construct for rpIGFBP-2. A construct consisting of IGFBP-2 cDNA in the pET-15b expression vector was used to produce recombinant protein in E. coli. The rpIGFBP-2 was purified by His-bind affinity chromatography followed by non-denaturing preparative gel electrophoresis and electro-elution.

\section{Recombinant porcine (rp) IGFBP-2}

A porcine thoracic aorta muscle cDNA library in pBluescript SK(-) vector was screened with a human IGFBP-2 cDNA probe to isolate several cDNA clones, which, by sequence analysis, were confirmed to encode porcine IGFBP-2 (GenBank AF120326). A cDNA fragment encoding the mature form (i.e. missing the signal peptide) of porcine IGFBP-2 was amplified from the cloned cDNA by Expand high-fidelity PCR using 30-mer oligodeoxyribonucleotides as primers (forward: 5-AGC CATATGGAGGTGCTGTTCCGCTGCCCG-3; reverse: 5-TTGCTCAGCCTGCATCCGCTGG GTGTGTGC-3). The PCR was performed in $50 \mu \mathrm{l}$ buffer (Buffer C, PCR Optimizer Kit, Invitrogen Corp., Carlsbad, CA, USA) and containing $50 \mathrm{ng}$ template, $200 \mathrm{ng}$ each primer, $250 \mu \mathrm{M}$ dNTPs, and $10 \%$ dimethyl sulfoxide. The PCR products were ligated to pCRTII vector (TA cloning Kit, Invitrogen) and recombinant clones were selected after transformation of BL21(DE3) Escherichia coli competent cells. The IGFBP-2 cDNA inserts were released from three such clones and individually subcloned between the unique NdeI and BlpI sites of the pET-15b vector (Novagen, Madison, WI, USA). The three resultant IGFBP-2-pET-15b expression constructs (Fig. 1) were then used to transform the BL21(DE3) strain of E. coli and sequenced in their entirety to confirm identity to wild-type sequence. Bacterial cells were grown to an $\mathrm{OD}_{600}$ of 0.6 in Luria-Bertani medium containing $100 \mu \mathrm{g} / \mathrm{ml}$ ampicillin, at which point, isopropyl- $\beta$-D-thiogalactopyranoside was added to a final concentration of $1 \mathrm{mM}$, to induce synthesis of IGFBP-2. Cells were grown for an additional $2 \mathrm{~h}$, and then centrifuged at $800 \boldsymbol{g}$ for $10 \mathrm{~min}$. Cell pellets were resuspended in binding buffer $(5 \mathrm{mM}$ imidazole, $0.5 \mathrm{M} \mathrm{NaCl}, 20 \mathrm{mM}$ Tris, $\mathrm{pH} \mathrm{7.9)}$ and sonicated on ice using five 2-3-s bursts. Sonicates were centrifuged at $47000 \boldsymbol{g}$ for $30 \mathrm{~min}$ at $4{ }^{\circ} \mathrm{C}$ and the supernatants and pellets (inclusion bodies) were separately collected. The rpIGFBP-2, which contains a hexa-histidine motif within its aminoterminal extension (Fig. 1), was purified by affinity chromatography on His-bind resin (Qiagen Inc., Valencia, CA, USA), followed by non-denaturing preparative PAGE and electro-elution.

\section{Cell culture}

Uterine endometrial GE cells were isolated from day 12 pregnant pig endometrium as previously described (Reed et al. 1996). All animal-use procedures were approved by the University of Florida Institutional Animal Care and Use Committee. Cells were resuspended $\left(0.5 \times 10^{6}\right.$ cells $\left./ \mathrm{ml}\right)$ 
in RPMI 1640 medium containing 10\% FBS, 1\% ABAM and $0.25 \mathrm{U} / \mathrm{ml}$ insulin and cultured at $37{ }^{\circ} \mathrm{C}$ in a $95 \%$ air $-5 \% \mathrm{CO}_{2}$ environment. Cells remained undisturbed (without medium change) for the first 3 days after plating. Thereafter, each culture was replenished with fresh medium every 2 days until cells reached the desired cell density.

\section{$\left[{ }^{3} \mathrm{H}\right]$ Thymidine incorporation assay}

Mitogenic effects of recombinant IGF-II, IGF-II analogs and IGFBP-2 were examined via the incorporation of $\left[{ }^{3} \mathrm{H}\right]$ thymidine into DNA of serumdeprived, confluent GE cells. Cells were seeded in six-well plates and grown to confluence at $37^{\circ} \mathrm{C}$. Cultures were then washed twice with Hanks' balanced salt solution (HBSS) and preconditioned in serum-free medium (containing ABAM) for $24 \mathrm{~h}$. Medium was changed to fresh (serum-free) medium and the cells incubated with or without the indicated treatments for $24 \mathrm{~h}$. After $20 \mathrm{~h}$, cells were pulselabeled with $2 \mu \mathrm{Ci}\left[{ }^{3} \mathrm{H}\right]$ thymidine for $4 \mathrm{~h}$. Cells were rinsed with phosphate-buffered saline $(\mathrm{pH} 7 \cdot 4)$, DNA was precipitated with $5 \%$ trichloroacetic acid, and incorporated radioactivity was measured by liquid scintillation counting.

\section{Ligand blot analysis}

Confluent GE cells were washed twice with HBSS and then preconditioned in serum-free medium for $24 \mathrm{~h}$. Medium was then removed and the cells rinsed and incubated in fresh serum-free medium for an additional $24 \mathrm{~h}$. Conditioned medium (CM) was collected after the second incubation and centrifuged briefly to remove cells and insoluble material. CM proteins were lyophilized and subjected to $12 \cdot 5 \%$ SDS-PAGE under non-reducing conditions, followed by electro-transfer to nitrocellulose membrane. The filters were blocked with Tris-buffered saline (TBS, $\mathrm{pH} 7 \cdot 4$ ) containing 1\% Carnation non-fat dry milk and incubated with $4 \times 10^{6}$ c.p.m. $\left[{ }^{125} \mathrm{I}\right]$-labeled rhIGF-II in this same buffer for $24 \mathrm{~h}$ at $4{ }^{\circ} \mathrm{C}$. After several washes with TBS, the air-dried membranes were exposed to BioMax film (Eastman Kodak Co, Rochester, NY, USA) for 24 to $48 \mathrm{~h}$ at $-80{ }^{\circ} \mathrm{C}$.

\section{Statistical analysis}

Differences in $\left[{ }^{3} \mathrm{H}\right]$ thymidine incorporation attributable to treatment were evaluated by least-squares analysis of variance using the General Linear Models procedure of the Statistical Analysis System (SAS 1985). When significant effects were detected $(P<0 \cdot 05)$, means were separated by preplanned

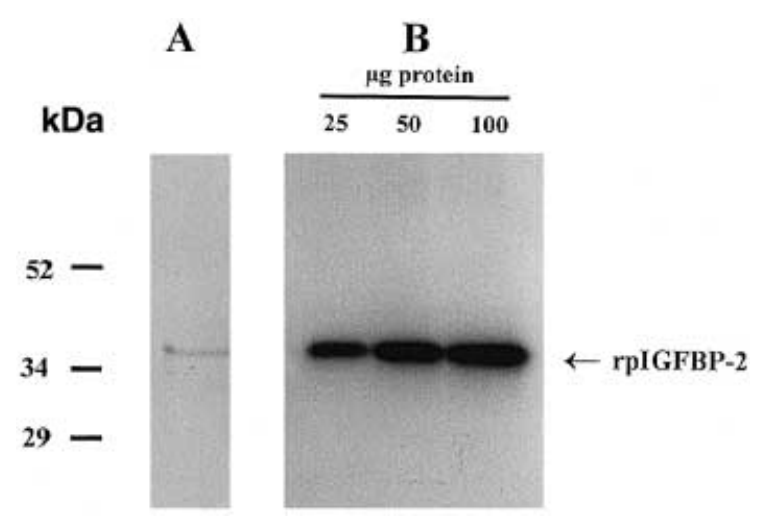

FIGURE 2. Electrophoretic analysis of rpIGFBP-2. A, Purified rpIGFBP-2 was resolved by $12 \cdot 5 \%$ SDS-PAGE under reducing conditions and stained with Coomassie Blue. B, Increasing amounts of purified rpIGFBP-2 were resolved in a $12 \cdot 5 \%$ SDS-PAGE under non-reducing conditions, electro-blotted to a nitrocellulose membrane, probed with $\left[{ }^{125} \mathrm{I}\right] \mathrm{rhIGF}-\mathrm{II}$, and visualized by autoradiography. The migration positions of pre-stained protein standards are indicated on the left.

orthogonal contrasts. Data are presented as means \pm S.E.M. of three independent experiments.

\section{RESULTS}

\section{Bacterial expression and functional analysis of rpIGFBP-2}

In the pig uterine endometrium, IGFBP-2 mRNA abundance is highly induced during periimplantation (around day 15, post-estrus) and reaches maximal levels by mid-pregnancy (Simmen et al. 1992, Song et al. 1996). This temporal expression pattern points to a physiological role for IGFBP-2 in implantation and subsequent fetomaternal interactions. To examine how this protein might interact with and affect uterine cell function, a construct consisting of pIGFBP-2 cDNA in pET-15b expression vector was generated and used to produce recombinant protein in E. coli (Figs 1, 2). Consistent with the size of porcine IGFBP-2 (Lee et al. 1991), the measured size of rpIGFBP-2 fused to the amino-terminal extension containing a hexa-histidine motif was $36 \mathrm{kDa}$ (Fig. 2). The crude recombinant protein was isolated predominantly from the supernatant fraction, rather than from the insoluble inclusion bodies (data not shown). The recombinant protein used for all experiments was subsequently purified to near homogeneity by His-bind affinity chromatography followed by 


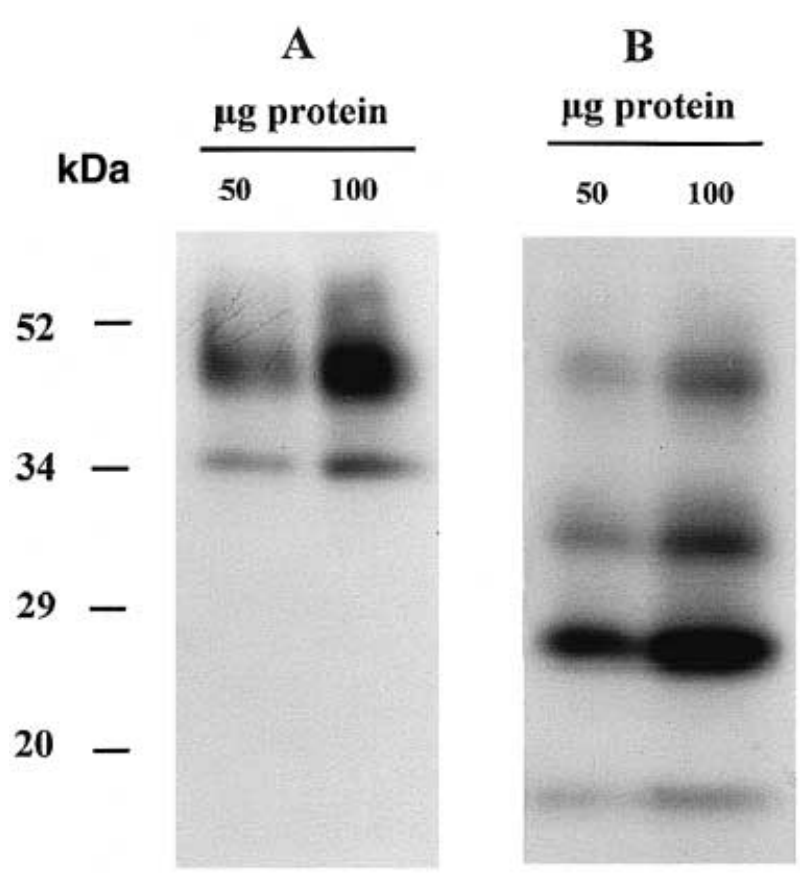

FIGURE 3. IGFBPs secreted by porcine uterine endometrial cells. CM proteins prepared from confluent monolayers of (A) human Hec-1A cells (positive control for IGFBP-2 and IGFBP-3) and (B) porcine GE cells were separated by $12 \cdot 5 \%$ SDS-PAGE under non-reducing conditions. The proteins were electroblotted to nitrocellulose membrane, probed with $\left[{ }^{125} \mathrm{I}\right] \mathrm{rhIGF}-\mathrm{II}$, and visualized by autoradiography. The two bands (in descending molecular mass) for Hec-1A CM represent IGFBP-3 and IGFBP-2. Note the absence of IGFBP-2 in GE cell CM. The migration positions of pre-stained protein standards are indicated on the left.

non-denaturing preparative gel electrophoresiselectro-elution and was not treated with thrombin. Ligand blot analysis of the purified protein with radio-labeled rhIGF-II revealed a sharp band that migrated at $36 \mathrm{kDa}$, demonstrating its functional IGF-binding activity (Fig. 2).

\section{IGFBPs in GE cell conditioned medium}

The presence and identities of IGFBPs in GE cell CM were examined by ligand blotting using $\left[{ }^{125} \mathrm{I}\right]$-labeled rhIGF-II. Four IGFBP bands with molecular masses of $48,31,23$, and $15 \mathrm{kDa}$ were detected in the GE cell CM (Fig. 3). IGFBP-2 (34 $\mathrm{kDa}$ protein) was not detected in GE cell CM by either ligand blot (Fig. 3) or Western blot analyses (data not shown). The highest-molecular-weight protein in GE CM appeared as a diffuse band between 53 and $45 \mathrm{kDa}$, which is consistent with the size of IGFBP-3 (Lee et al. 1991, Ko et al. 1994).

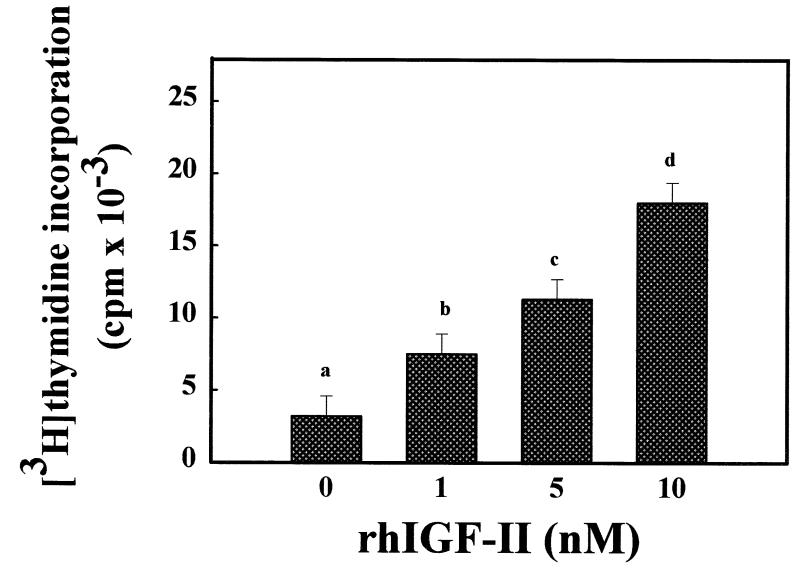

FIGURE 4. Mitogenic response of uterine endometrial GE cells to IGF-II. GE cells were grown to confluence and then incubated in serum-free medium for $24 \mathrm{~h}$. The cell monolayers were rinsed with HBSS and incubated with increasing concentrations of rhIGF-II in serumfree medium for an additional $24 \mathrm{~h}$. After $20 \mathrm{~h}$ of this incubation, cells were pulse-labeled with $2 \mu \mathrm{Ci}$

$\left[{ }^{3} \mathrm{H}\right]$ thymidine for $4 \mathrm{~h}$. The mitogenic response to each treatment was determined in triplicate and results represent the mean \pm s.E.M. of three independent experiments for each rhIGF-II concentration. Each experiment represents cells isolated from an individual pig on day 12 of pregnancy. Means with differing superscripts are statistically significantly different $(P<0 \cdot 05)$.

\section{Mitogenic effects of IGF peptides in GE cells}

To examine the role of IGF-II in uterine cell growth, serum-deprived GE cells were treated with various concentrations of rhIGF-II and its analog, $\left[\mathrm{Leu}^{27}\right]-\mathrm{IGF}-\mathrm{II}$, for $20 \mathrm{~h}$ and pulsed with $\left[{ }^{3} \mathrm{H}\right]$ thymidine for $4 \mathrm{~h}$. IGF-II stimulated DNA synthesis in porcine endometrial $\mathrm{GE}$ cells in a dosedependent fashion (Fig. 4). [Leu $\left.{ }^{27}\right]-$ IGF-II, an analog with highly selective affinity for the IGF-II receptor (little or no binding to the type I receptor), increased mitogenesis of GE cells to the same extent as did native IGF-II (Fig. 5). When added to the culture medium in combination with an equimolar concentration of rhIGF-I, native IGF-II and its analog stimulated $\left[{ }^{3} \mathrm{H}\right]$ thymidine incorporation to a greater extent than did rhIGF-I alone (Fig. 6). These collective findings suggest the involvement of both IGF receptor types in uterine GE cell mitogenesis.

\section{rpIGFBP-2 mediation of GE cell proliferation}

To examine whether IGFBP-2 functionally interacts with IGF-II to mediate uterine epithelial cell 

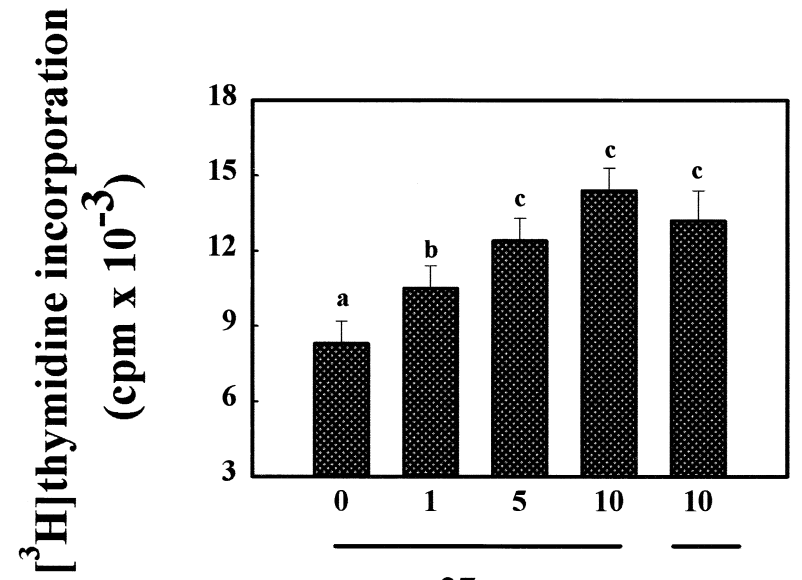

[Leu ${ }^{27}$ ]IGF-II rhIGF-II

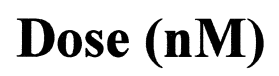

FIGURE 5. Effect of $\left[\mathrm{Leu}^{27}\right]-\mathrm{IGF}-\mathrm{II}$ on $\left[{ }^{3} \mathrm{H}\right]$ thymidine incorporation into DNA of porcine endometrial GE cells. Confluent monolayers of GE cells were preconditioned in serum-free medium for $24 \mathrm{~h}$ and then treated with increasing concentrations of $\left[\mathrm{Leu}^{27}\right]-\mathrm{IGF}$ II for an additional $24 \mathrm{~h}$. After $20 \mathrm{~h}$ of this incubation, cells were pulse-labeled with $2 \mu \mathrm{Ci}\left[{ }^{3} \mathrm{H}\right]$ thymidine for $4 \mathrm{~h}$. The mitogenic response to each treatment was determined in triplicate and results represent the mean \pm s.E.M. of three independent experiments for each concentration of the IGF-II analog. Each experiment represents endometrial $\mathrm{GE}$ cells isolated from an individual pig on day 12 of pregnancy. Means with different superscripts are statistically significantly different $(P<0 \cdot 05)$.

growth, serum-deprived GE cells were incubated with various concentrations of rpIGFBP-2 in the presence or absence of exogenous IGF-II. Physiological doses (nM) of rpIGFBP-2 increased IGFII-dependent DNA synthesis in primary cultures of GE cells (Fig. 7). These effects of rpIGFBP-2 on cellular DNA synthesis were also demonstrated in the absence of exogenous rhIGF-II (Fig. 8). Lastly, Des(1-6)IGF-II, an analog with markedly reduced affinity for IGFBPs, stimulated DNA synthesis by 1.5-fold in GE cells and cotreatment with an equimolar concentration of rpIGFBP-2 further increased Des(1-6)IGF-II-induced mitogenesis of these cells (Fig. 9).

\section{DISCUSSION}

The present study examined the potential involvement and functional interactions of IGF-II and a major uterine-expressed IGF-II binding protein,

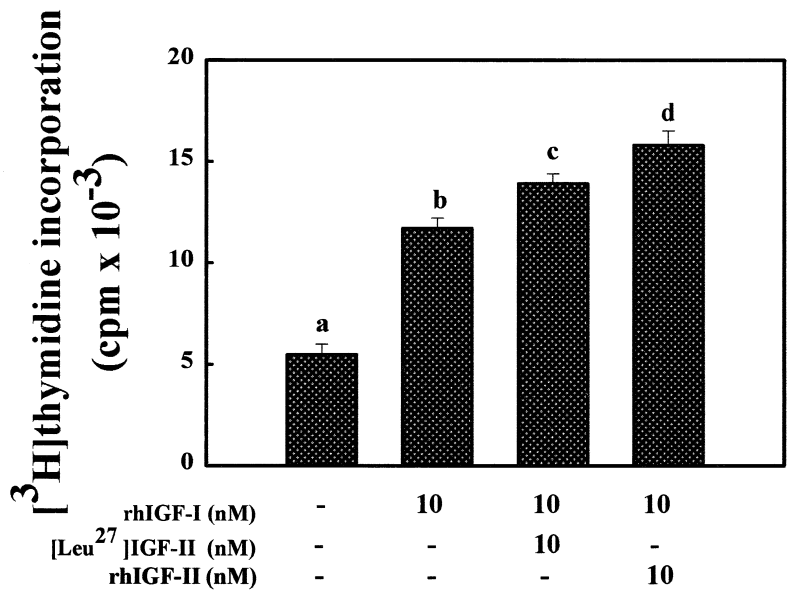

\section{Treatment}

FIGURE 6. Additive effects of IGF peptides on DNA synthesis of porcine endometrial cells. Confluent monolayers of GE cells were washed with HBSS and incubated in serum-free medium for $24 \mathrm{~h}$. Cells were then incubated with or without the indicated peptides for an additional $24 \mathrm{~h}$. After $20 \mathrm{~h}$ of this incubation, cells were pulse-labeled with $2 \mu \mathrm{Ci}\left[{ }^{3} \mathrm{H}\right]$ thymidine for $4 \mathrm{~h}$. Mitogenic responses were determined in triplicate and results represent the mean \pm S.E.M. for three independent experiments. Each experiment represents cells isolated from an individual pig on day 12 of pregnancy. Means with different superscripts are statistically significantly different $(P<0 \cdot 05)$.

IGFBP-2, in mediating uterine endometrial cell proliferation. Our results demonstrating the mitogenic activities of these proteins, alone and in combination, suggest important uterine roles in vivo, not otherwise demonstrated by the transgenic and knock-out methodologies used in studies of uterine IGF-I (Baker et al. 1996, Wang et al. 1997).

The presence of both $\mathrm{IGF}$ receptor types on most cells and the cross-reactivity of ligands for binding to these receptors have made it difficult to determine the specific receptor type that mediates a given biological response. Although previous studies suggested that cell signaling by both IGF-I and IGF-II is mediated primarily through the tyrosine kinase IGF-I receptor (reviewed in Jones \& Clemmons 1995), other reports indicated that IGF-II may elicit some of its effects through the non-tyrosine kinase IGF-II-cation-independent mannose-6-phosphate receptor (Beguinot et al. 1985, Tally et al. 1987, Minniti et al. 1992, Takigawa et al. 1997). To understand further the mechanism by which IGF-II affects uterine function, we examined the IGF receptor subtype(s) 


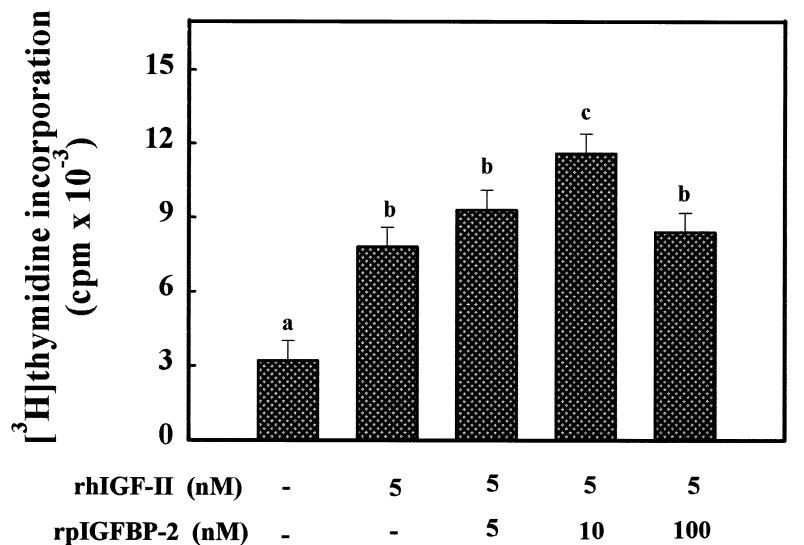

Treatment

FIGURE 7. Dose-dependent effect of rpIGFBP-2 on IGF-II-induced $\left[{ }^{3} \mathrm{H}\right]$ thymidine incorporation into DNA of uterine endometrial cells. Confluent monolayers of GE cells were incubated in serum-free medium for $24 \mathrm{~h}$. Cells were rinsed and then incubated with rhIGF-II $(5 \mathrm{nM})$ in the presence or absence of various concentrations of rpIGFBP-2 in serum-free medium for $24 \mathrm{~h}$. After $20 \mathrm{~h}$ of this incubation, cells were pulse-labeled with $2 \mu \mathrm{Ci}\left[{ }^{3} \mathrm{H}\right]$ thymidine for $4 \mathrm{~h}$. The mitogenic response to each treatment combination was determined in triplicate and results represent the mean \pm s.E.M. for three independent experiments (each experiment represents cells isolated from an individual pig on day 12 of pregnancy). Means with different superscripts are statistically significantly different $(P<0 \cdot 05)$.

that mediates IGF-II-induced DNA synthesis in porcine endometrial $\mathrm{GE}$ cells, by means of $\left[\mathrm{Leu}^{27}\right]-$ IGF-II. This analog interacts with the IGF-II-mannose-6-phosphate receptor with normal affinity, but has negligible affinity for IGF-I and insulin receptors (Beukers et al. 1991, Bürgisser et al. 1991, Sakano et al. 1991). [Leu $\left.{ }^{27}\right]$-IGF-II increased DNA synthesis in a dose-dependent manner in porcine endometrial GE cells, and these stimulatory effects were detected at concentrations (nM range) at which the analog interacts only with the IGF-II receptor. Moreover, [Leu $\left.{ }^{27}\right]$-IGF-II or native IGF-II, in combination with equimolar concentrations of rhIGF-I, stimulated $\left[{ }^{3} \mathrm{H}\right]$ thymidine incorporation to greater extents than did IGF-I alone. These findings suggest the presence of functional IGF-II-mannose-6-phosphate receptors on porcine uterine epithelial cells, and point to the involvement of the type II IGF receptor, distinct from that of IGF-I, in mitogenic signaling of these cells.

Significant uterine endometrial IGFBP-2 expression has been demonstrated for a number of mammals (Giudice et al. 1991, Rechler 1993, Song

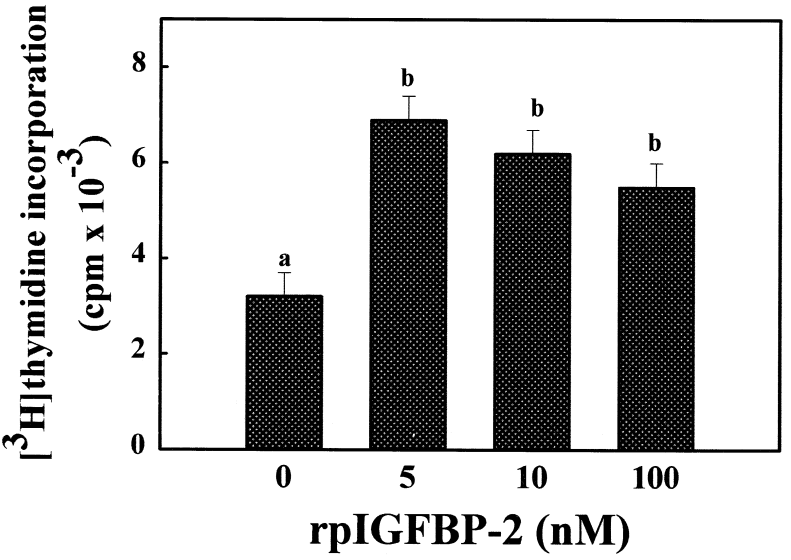

FIGURE 8. rpIGFBP-2 modulation of basal mitogenesis of uterine endometrial cells. Confluent monolayers of $\mathrm{GE}$ cells were incubated in serum-free medium for $24 \mathrm{~h}$. Cells were rinsed with HBSS and further incubated in the presence of increasing concentrations of rpIGFBP-2 for $24 \mathrm{~h}$. After $20 \mathrm{~h}$ of this incubation, cells were pulselabeled with $2 \mu \mathrm{Ci}\left[{ }^{3} \mathrm{H}\right]$ thymidine for $4 \mathrm{~h}$. The mitogenic response to each treatment was monitored in triplicate and results shown are the mean \pm S.E.M. for three independent experiments for each concentration of rpIGFBP-2. Means with different superscripts are statistically significantly different $(P<0 \cdot 05)$.

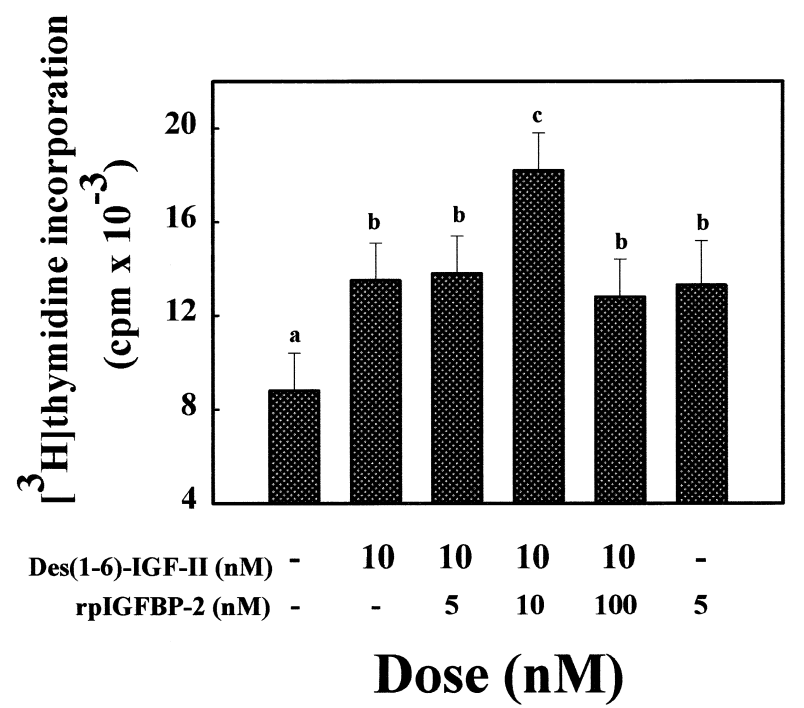

FIGURE 9. Additive effects of Des(1-6)IGF-II and IGFBP-2 on $\left[{ }^{3} \mathrm{H}\right]$ thymidine incorporation by porcine endometrial cells. Responses were determined in triplicate during each of three independent experiments. Each experiment utilized cells from a different pig on day 12 of pregnancy. Means with different superscripts are statistically significantly different $(P<0 \cdot 05)$. 
et al. 1996, Cerro \& Pintar 1997). In porcine uterus, this expression is induced during the periimplantation period and reaches maximal levels by mid-pregnancy. In the present study, we sought to examine whether this binding protein interacts with its major ligand, IGF-II, to modulate uterine endometrial cell proliferation during early pregnancy. In contrast to its well-documented inhibitory effects on DNA synthesis in tumor cell lines (reviewed in Rechler 1993 and Jones \& Clemmons 1995), rpIGFBP-2 increased both basal and exogenous IGF-II-stimulated $\left[{ }^{3} \mathrm{H}\right]$ thymidine incorporation in primary cultures of porcine endometrial epithelial cells. Consistent with these data, Bar et al. (1989) previously reported that partially purified IGFBP-2 was a weak potentiator of IGF-I-induced glucose transport and aminoisobutyric acid uptake in microvascular endothelial cells. Likewise, bovine IGFBP-2 was shown to potentiate the mitogenic response of aortic smooth muscle cells to IGF-I by $80 \%$ in the presence of low concentrations of plateletpoor plasma (Bourner et al. 1992). In addition, the homozygous IGFBP-2 null mutant mouse is characterized by decreased spleen size (Pintar et al. 1996), suggestive of a stimulatory role for this IGFBP in tissue growth. The observation that exogenous Des(1-6)IGF-II, an analog with minimal affinity for IGFBPs, and exogenous rpIGFBP-2 had additive effects on GE cell mitogenesis further suggests that IGFBP-2 modulation of uterine epithelial cell growth may involve both IGF-dependent and IGFindependent pathways.

In summary, these results demonstrate that IGFBP-2 and IGF-II are potent local mitogens for the uterine epithelium and that this effect of both proteins is, in all likelihood, not wholly mediated by the type I IGF receptor. These results are intriguing, in light of the presence of significant amounts in porcine uterus of truncated (Des)IGF-I (Ballard et al. 1996), which, together with IGF-II and IGFBP-2, might mediate proliferative and differentiative events in the endometrium via multiple parallel or convergent pathways.

\section{ACKNOWLEDGEMENTS}

This work was supported, in part, by NIH Grant HD 21961 and USDA Grant 95-37206-2317. This paper is published as Journal Series No. R-06900 from the Florida Agricultural Experiment Station.

The authors gratefully acknowledge W Collante, F J Michel, $T$ Chung and $G$ Zhao for expert technical assistance, and other members of our laboratories for assistance with breeding of animals and collection of tissues.

\section{REFERENCES}

Baker J, Hardy MP, Zhou J, Bondy C, Lupu F, Bellve AR \& Efstratiadis A 1996 Effects of an Igf1 gene null mutation on mouse reproduction. Molecular Endocrinology 10 913-918.

Ballard FJ, Wallace JC, Francis GL, Read LC \& Tomas FM 1996 Des(1-3)IGF-I: a truncated form of insulin-like growth factor-I. International Fournal of Biochemistry and Cell Biology 28 1085-1087.

Bar RS, Booth BA, Boes M \& Dake BL 1989 Insulin-like growth factor-binding proteins from vascular endothelial cells: purification, characterization, and intrinsic biologic activities. Endocrinology 125 1910-1920.

Beguinot F, Kahn CR, Moses AC \& Smith RJ 1985 Distinct biologically active receptors for insulin, insulin-like growth factor I, and insulin-like growth factor II in cultured skeletal muscle cells. Fournal of Biological Chemistry 260 15892-15898.

Beukers MW, Oh Y, Zhang H, Ling N \& Rosenfeld RG 1991 $\left[\mathrm{Leu}^{27}\right]$ insulin-like growth factor II is highly selective for the type-II IGF receptor in binding, cross-linking and thymidine incorporation experiments. Endocrinology 128 1201-1203.

Bourner MJ, Busby WH, Siegel NR, Krivi GG, McCusker RH \& Clemmons DR 1992 Cloning and sequence determination of bovine insulin-like growth factor binding protein-2 (IGFBP-2): comparison of its structural and functional properties with IGFBP-1. Fournal of Cellular Biochemistry 48 215-226.

Bürgisser DM, Roth BV, Giger R, Lüthi C, Weigl S, Zarn J \& Humbel RE 1991 Mutants of human insulin-like growth factor II with altered affinities for the type 1 and type 2 insulin-like growth factor receptor. Fournal of Biological Chemistry 266 1029-1033.

Casella SJ, Han VK, D'Ercole AJ, Svoboda ME \& Van Wyk JJ 1986 Insulin-like growth factor II binding to the type I somatomedin receptor. Evidence for two high affinity binding sites. Fournal of Biological Chemistry 261 9268-9273.

Cerro JA \& Pintar JE 1997 Insulin-like growth factor binding protein gene expression in the pregnant rat uterus and placenta. Developmental Biology 184 278-295.

Gadsby JE, Heap RB \& Burton RD 1980 Oestrogen production by blastocyst and early embryonic tissue of various species. Fournal of Reproduction and Fertility 60 409-417.

Geisert RD, Brookbank JW, Roberts RM \& Bazer FW 1982 Establishment of pregnancy in the pig: II. Cellular remodeling of the porcine blastocyst during elongation on day 12 of pregnancy. Biology of Reproduction 27 941-955.

Ghahary A \& Murphy LJ 1989 Uterine insulin-like growth factor-I receptors: regulation by estrogen and variation throughout the estrous cycle. Endocrinology 125 597-604.

Giudice LC, Milkowski DA, Lamson G, Rosenfeld RG \& Irwin JC 1991 Insulin-like growth factor binding proteins in human endometrium: steroid-dependent messenger ribonucleic acid expression and protein synthesis. Fournal of Clinical Endocrinology and Metabolism 72 779-787.

Green ML, Simmen RCM \& Simmen FA 1995 Developmental regulation of steroidogenic enzyme gene expression in the periimplantation porcine conceptus: a paracrine role for insulin-like growth factor-I. Endocrinology 136 3961-3970.

Hofig A, Michel F, Simmen FA \& Simmen RCM 1991 Constitutive expression of uterine receptors for insulin-like growth factor-I during the peri-implantation period in the pig. Biology of Reproduction 45 533-539.

Jones JI \& Clemmons DR 1995 Insulin-like growth factors and their binding proteins: biological actions. Endocrine Reviews 16 3-34. 
Ko Y, Simmen RCM, Lee CY \& Simmen FA 1994 Reversion to the nontransformed phenotype of tsSV40-transformed uterine epithelial cells is accompanied by decreased mitogenic responsiveness to IGFs and enhanced secretion of at least five IGF binding proteins. Endocrine 2 495-504.

Kojima I, Nishimoto I, Iiri T, Ogata E \& Rosenfeld RG 1988 Evidence that type II insulin-like growth factor receptor is coupled to calcium gating system. Biochemical and Biophysical Research Communications 154 9-19.

Lee CY, Bazer FW, Etherton TD \& Simmen FA 1991 Ontogeny of insulin-like growth factors (IGF-I and IGF-II) and IGF-binding proteins in porcine serum during fetal and postnatal development. Endocrinology 128 2336-2344.

Letcher R, Simmen RCM, Bazer FW \& Simmen FA 1989 Insulin-like growth factor-I expression during early conceptus development in the pig. Biology of Reproduction 41 1143-1151.

Minniti CP, Kohn EC, Grubb JH, Sly WS, Oh Y, Muller HL, Rosenfeld RG \& Helman LJ 1992 The insulin-like growth factor II (IGF-II)/mannose 6-phosphate receptor mediates IGF-II-induced motility in human rhabdomyosarcoma cells. Fournal of Biological Chemistry 267 9000-9004.

Misra P, Hintz RL \& Rosenfeld RG 1986 Structural and immunological characterization of insulin-like growth factor II binding to $1 \mathrm{M}-9$ cells. Fournal of Clinical Endocrinology and Metabolism 63 1400-1405.

Pescovitz OH, Johnson NB \& Berry SA 1991 Ontogeny of growth hormone releasing hormone and insulin-like growth factors-I and -II messenger RNA in rat placenta. Pediatric Research 29 510-516.

Pintar JE, Cerro JA \& Wood TL 1996 Genetic approaches to the function of insulin-like growth factor-binding proteins during rodent development. Hormone Research 45 172-177.

Pusateri AE, Rothschild MF, Warner CM \& Ford SP 1990 Changes in morphology, cell number, cell size and cellular estrogen content of individual littermate pig conceptuses on days 9 to 13 of gestation. Fournal of Animal Science $\mathbf{6 8}$ 3727-3735.

Rechler MM 1993 Insulin-like growth factor binding proteins. Vitamins and Hormones 47 1-114.

Reed KL, Badinga L, Davis DL, Chung TE \& Simmen RCM 1996 Porcine endometrial glandular epithelial cells in vitro: transcriptional activities of the pregnancy-associated genes encoding antileukoproteinase and uteroferrin. Biology of Reproduction 55 469-477.

Sakano K, Enjoh T, Numata F, Fujiwara H, Marumoto Y, Higashihashi N, Sato Y, Perdue JF \& Fujita Yamaguchi Y 1991 The design, expression, and characterization of human insulin-like growth factor II (IGF-II) mutants specific for either the IGF-II/cation-independent mannose 6-phosphate receptor or IGF-I receptor. Fournal of Biological Chemistry $26620626-20635$.

SAS 1985 SAS User's Guide: Statistics, pp 433-506. Cary, NC: SAS Institute Inc.

Simmen RCM, Simmen FA, Ko Y \& Bazer FW 1989 Differential growth factor content of uterine luminal fluids from Large White and prolific Meishan pigs during the estrous cycle and early pregnancy. Fournal of Animal Science 67 1538-1545.

Simmen FA, Simmen RCM, Geisert RD, Martinat-Botte F, Bazer FW \& Terqui M 1992 Differential expression, during the estrous cycle and pre- and postimplantation conceptus development, of messenger ribonucleic acids encoding components of the pig uterine insulin-like growth factor system. Endocrinology 130 1547-1556.

Song S, Lee CY, Green ML, Chung CS, Simmen RCM \& Simmen FA 1996 The unique endometrial expression and genomic organization of the porcine IGFBP-2 gene. Molecular and Cellular Endocrinology 120 193-202.

Steele-Perkins G \& Roth RA 1990 Monoclonal antibody $\alpha 1$ R-3 inhibits the ability of insulin-like growth factor II to stimulate a signal from type I receptor without inhibiting its binding. Biochemical and Biophysical Research Communications 171 1244-1251.

Steele-Perkins G, Turner J, Edman JC, Hari J, Pierce SB, Stover C, Rutter WJ \& Roth RA 1988 Expression and characterization of a functional human insulin-like growth factor I receptor. Fournal of Biological Chemistry 263 11486-11492.

Takigawa M, Okawa T, Pan H-O, Aoki C, Takahashi K, Zue J-D, Suzuki F \& Kinoshita A 1997 Insulin-like growth factors I and II are autocrine factors in stimulating proteoglycan synthesis, a marker of differentiated chondrocytes, acting through their respective receptors on a clonal human chondrosarcoma-derived chondrocyte cell line, HCS-2/8. Endocrinology 138 4390-4400.

Talavera F, Reynolds RK, Roberts JA \& Menon KMJ 1990 Insulin-like growth factor I receptors in normal and neoplastic human endometrium. Cancer Research $\mathbf{5 0}$ 3019-3024.

Tally M, Li CH \& Hall K 1987 IGF-2 stimulated growth mediated by the somatomedin type 2 receptor. Biochemical and Biophysical Research Communications 148 811-816.

Wang J, Niu W, Nikiforov Y, Naito S, Chernausek S, Witte D, LeRoith D, Strauch A \& Fagin JA 1997 Targeted overexpression of IGF-I evokes distinct patterns of organ remodeling in smooth muscle cell tissue beds of transgenic mice. Fournal of Clinical Investigation 100 1425-1439.

REVISED MANUSCRIPT RECEIVED 14 May 1999 